\title{
Adorno, Obama, and Empire: Reflections on the U.S. Presidential Election and the Next President
}

Lukas Kaelin

\section{Introduction}

\begin{abstract}
A s tempting as it might be, politics is a difficult field for philosophers. Well known are Plato's and Heidegger's attempt to influence the 1 political developments of their time, which went badly wrong. ${ }^{1}$ Much safer is it to provide an interpretation of current political events, which is the aim of this paper. The paper attempts to philosophically assess the recent U.S. presidential race and to look at some aspects of the underlying beliefs of Barack Obama that aided him in his campaign. The philosophical framework used in order to interpret the political events are mainly from the Critical Theory of Theodor W. Adorno and the neo-Marxist approach of Michael Hardt and Antonio Negri. Further observations will concentrate on the logic and attraction of the electoral process and the dialectical logic of Sarah Palin's statements. The first part will discuss the form of U.S. electoral politics, especially the perpetual campaign, whereas the second part will put the policies of the next U.S. president into a philosophical context.
\end{abstract}

\section{Part I: With Adorno on the Campaign Trail}

The perpetual ongoing election campaign for the United States presidency is a political spectacle unmatched by any other political process on this globe: Campaigning starts right after the mid-term election, preparations and speculations start even earlier. The spectacle attracts the interest of the whole world and even the primaries almost a year before election day are discussed from Venezuela to the Philippines and from Nigeria to Switzerland. No other political event on earth attracts as nearly as much attention. The first part of my paper will highlight some aspects concerning the form rather then the content of this spectacle. The form of the election process will be

1 Towards the end of his life, Plato attempted to implement his vision of a kingdom guided by a philosopher king in Sizily with the local herrscher, which ended in a major disappointment for the philosopher. Heidegger's flirt with National Socialism in the early 1930 s - he saw in the movement initially the spiritual renewal of modern time-was a massive misunderstanding of the very core of this political movement. 


\section{ADORNO, OBAMA, AND EMPIRE}

examined from three different angles: First, I will look at the election campaign with the framework of Adorno's Critical Theory, second, the logic and attraction of the seemingly eternal election process will be analyzed in analogy with economic theory applied to sport events, and lastly, sort of ironically, different statements of the Republican Vice-presidential candidate Sarah Palin will be examined for their dialectical logic.

\section{Minima Moralia in a time of Media Politics}

Alluding to Aristotle's Magna Moralia, Theodor W. Adorno, a Jewish immigrant to the United States writing during World War II, has written Minima Moralia. The implicit premise of this book, presented in fragments or aphorisms, is that all we can hope for in terms of morality are minimal rules of conduct, as the good life becomes increasingly difficult in problematic social circumstances, a temperament which the book's subtitle evokes: "Reflections from the damaged life." 2 Elsewhere, Adorno would point out the social embeddedness of any type of ethics, and would refute principled ethics either of the Kantian or Utilitarian variant. ${ }^{3}$ Within a bad life, as Adorno points out, a good life is not possible. Given the interconnections of modern life, it is impossible to create an unaffected island of good behavior in a society governed by greed and corruption; after all, greed is what capitalism inherently drives.

Although living in the United States of Roosevelt's New Deal for about a decade, Adorno did not apply his bleak culture critique to American politics, dedicating his time more to what he called culture industry. However, it might well be interesting to analyze with Adorno's conceptual framework the working of American politics in our time. One of the recurring difficulties of Adorno in his academic life in the U.S. was his reluctance to have a factual approach to philosophy. ${ }^{4}$ Adorno saw in an overly reliance on facts a positivist failure of understanding the how and why these facts are discussed in a certain discourse. Looking at the perpetual presidential campaign, facts about involvements of candidates in morally ambivalent behavior pop-up every couple of days: Did Palin misuse her power in what has become to be known "troopergate?" What was the relationship of Obama with former domestic terrorist William Ayers? How often did McCain vote with outgoing President Bush? Etc. However, the reliance on these facts hides important questions of why these issues are in play and how they matter. The mere knowledge of facts does not bring about a more human life. As Horkheimer and Adorno would put it: "The flood of

\footnotetext{
2 See Theodor W. Adorno, Minima Moralia: Reflections from Damaged Life, trans. by E.F.N. Jephcott (London: NLB, 1974).

3 Theodor W. Adorno, Problems of Moral Philosophy, trans. by Rodney Livingstone (California: Stanford University Press, 2001), esp. 166.

4 Theodor W. Adorno, „Wissenschaftliche Erfahrungen in Amerika," in Gesammelte Schriften, Band 10. (Suhrkamp: Frankfurt am Main, 1997), 702-738.
} 
precise information . . . make[s] people smarter and more stupid at once."5 People will be more able to pinpoint to innumerous details_-facts—but will lose sight of the underlying issues at stake and fail to question the very mechanism of medial electoral politics.

But will people really fail to question the circus of the perpetual election campaign with its continuous excitement production? Hardly, as individuals are still more intelligent than the media circus pretends, as Adorno points out, however, the individual's autonomous thought is overwhelmed by the sheer strength of the mass media. Although dictated by a few in number, the individual will experience the power of the hegemonic discourse as overwhelming: "What is done to all by the few always takes the form of the subduing of individuals by the many: the oppression of society always bears features of oppression by a collective." 6 The individual is all but powerless, when faced with the overpowering discourse and continuous presentations of facts by the mass media.

Moreover, there is a second problematic aspect on the contemporary reliance on facts in the political campaign setting. These discussion from Troopergate to William Ayers inevitably end up as phony debates about the right interpretation of a certain state of affairs. Truth is permanently suspended. In the light of highly mediated political campaigns the question about telling the truth inevitably gets distorted and is reduced to an egoistic consequentialism. Telling a lie is preferable as long as it increases one's own chances of winning and the opponent is not able to detect it before Election Day. Questions about the right thing to do for a certain campaign are discussed mainly under the topic of possible damages and benefits. Watching discussions among pundits on major television networks, the question "Is it true?" or "Is it important?" hardly matter compared to the question "Will it increase the chances of the candidate?" Questions of truth are translated into questions of power, with dire consequences. "The conversion of all questions of truth into questions of power, a process that truth itself cannot escape if it is not to be annihilated by power, not only suppresses truth . . . but has attacked the very heart of the distinction between true and false." 7 This transformation of politics - which is by no means new-reduces it to the simple Schmittian friend-enemy-distinction. Politics regresses to an entirely partisan endeavor; a partisanship which ironically is criticized throughout the very political system that reinforces it. No surprise then that this friendenemy-logic-which, as Adorno points out, has its roots in the New Testament word "He who is not with me is against me" primary political category in the post- $9 / 11$ world. Adorno calls this "a priori reduction to the friend-enemy relationship . . . one of the primal phenomena

${ }^{5}$ Max Horkheimer and Theodor W. Adorno, Dialectic of Enlightenment, trans. by John Cumming (New York: Continuum, 1972), xvii.

${ }^{6}$ Ibid., 16.

7 Adorno, Minima Moralia, 109, $\$ 71$.

${ }^{8}$ Luke 11:23; Matthew 12:30. 


\section{ADORNO, OBAMA, AND EMPIRE}

of the new anthropology." 9 An anthropology which undercuts freedom and reduces it to a mere choice between black and white.

\section{The Logic and Attraction of the Election Campaign}

What has been said in the first part is not particularly new, as Adorno pointed out more than 60 years ago that in "politics debate has long since been supplanted by the assertion of power." 10 What is new, however, is the almost two years lasting perpetual election campaign. I will look at this phenomenon from the viewer's perspective dwelling upon economic theory as applied to sport events. The question to be answered is a simple one: why does an election in a nation-state stimulate so much interest and media coverage across the globe for more than an entire year and transforms democracy into a perpetual election campaign? Obama, for example, publicly launched his campaign in February 2007 raising already more than $\$ 50$ Million during the first half of 2007. Given wide-ranging speculation about possible candidates, perpetual polls and ratings, and the midterm elections, one is justified to speak with Hegel that after the election is before the election.

In order to answer the above question, I will turn to a puzzling question in the media coverage on sports. Helmut Dietl and Egon Franck, two economists teaching at the University of Zürich, asked the question why the breakfast of the national soccer team gets more media coverage that the new national athletics record in $4 \times 100$ meter relay. ${ }^{11}$ Instead of reporting about this new national record, the media was pondering about trivialities such as the diet of the national team, about which players share a hotel room and the color of the captain's armband. The reason is not that soccer players achieve a higher performance than track and field athletes. From the perspective of sports medicine, athletics or rowing requires higher physical effort than soccer. ${ }^{12}$ The reason for the success of soccer in the media-or the dominance of the comprehensive coverage of the US election in the media-must lie elsewhere.

Mainly two aspects give soccer an edge over sports like athletics, when looked at these sports as consumable products: First, athletics is based on objective performance counted in meters and seconds and the quality of a competition is judged according to the records achieved. This, however, leads to a vicious circle: every record sets a new standard on which the following events are measured and it gets more and more difficult to match these standards. In soccer, on the other hand, relative performance matters, namely a victory over the other team. In this way it escapes the vicious circle of ever higher standards. A second plus factor for soccer is that almost every game is embedded in a year long championship. The quality of a single game receives an increased importance given the consequences that follow for the

9 Adorno, Minima Moralia, 132, $\$ 85$.

${ }^{10}$ Ibid., 137, $\$ 90$.

11 Helmut Dietl and Egon Franck, „Das Frühstück der Nationalspieler interessiert mehr als der Staffelrekord,“ in Neue Zürcher Zeitung (June 17, 2008), 55.

${ }^{12}$ Ibid. 
championship. Athletics on the other hand is organized as single events not embedded in a hierarchical championship. Simply put: while the athletics consumer will just read in the papers about the results of last weekend's competition, the soccer consumer will read about the result of the games and the way these games have an impact on the overall championship. The attention and curiosity of the consumer is kept alive and increased, and an ascending media-supported circle is launched: more viewers lead to a higher media interest. The better media coverage attracts sponsors, who in turn allow for better athletes and infrastructure, which in turn attracts more viewers, etc. ${ }^{13}$

However, from this media induced cycles all sports focusing on relative performance could profit. Why is soccer the sport that dominates the media (at least in most parts of the world)? Dietl and Franck explain this in the following way: In order to enjoy a sport, one needs to build up knowledge about this sport, in the same way as art appreciation presupposes knowledge of art. The viewers need to build up consumer capital, which can be built up by playing as well as watching the game. The more consumer capital a fan has built up, the more he gets attached to the information provided in this field of his interest. Given time constraints, a certain viewer needs to select certain areas of expertise. Which area (i.e. which sport) will be chosen depends on the interests of the social environment: being a fan of a particular sport consists as well in exchanging ideas and analyzing games. This leads to a kind of snowball effect pushing a certain sport, which has got to a critical mass, over the top. In most countries, soccer has reached that critical mass first; one reason might be the simplicity of the game enabling a big number of people to build a certain expertise in the game. Empirical evidence shows as well that once a sport has reached this privileged status in society, it is difficult for other sports to challenge its hegemony. ${ }^{14}$

This logic of sports consumerism has a strong parallel with the structure of the U.S. presidential race (the term race already is borrowed from sports). First of all, the year of the presidential election is structured in series of decisive moments, starting with the primaries from early January until June, the VP pick and the two party conventions in late August early September, the televised debate in early October until the election on November $4^{\text {th }}$. All these events with all the media noise surrounding them-polls, expert opinions, panel discussions, projections-follow closely the logic of sports events. Every primary election has a winner, a victory, however, to be understood in the context of the larger race. The key question in the presidential debates is not so much what is said (or whether it is the truth) but rather whether the candidate managed to reach and convince undecided voters and whether their poll numbers changed. The above described ascending circle of viewers interest, media attention, sophisticated tools, panel discussion, expert opinions lead to an ever increasing production of data, opinions, and projections. The

$$
{ }^{13} \text { Ibid. }
$$




\section{ADORNO, OBAMA, AND EMPIRE}

largeness of the country and the financial might of its media make the American election appear like a huge "sports event" in a global scale.

On the consumer side, the viewer starts to build up consumer capital, which allows him to understand, order, and discuss the successive events of the presidential race. The succession of heavily covered events-primaries, debates, VP picks, changing poll numbers-keeps the viewer interested and provides him with new information to increase and actualize his consumer capital. Once the viewer has acquired a certain expertise, he then shares and discusses his opinion and increases the circulation of knowledge and draws more people into following this political event. The media coverage consists, among other things, the release of sometimes more than 30 state polls and over 10 national polls a day (!), websites commenting on even the smallest event and occurrence on the campaign trail and the major television networks providing quite predictable expert opinions. In the coverage of the election campaign, the play with expectations is brought to perfection: any of the next primaries is always the decisive one, any debate might be the "game-changer," and any disclosure of previously unknown information might shift the momentum to the other candidate.

\section{The Dialectics of Palin}

When Bush was running for president in 2000, he was known for his folksy style and his struggle not only with grammar but with the meaningful construction of sentences. Famous are lines like "I know the human being and fish can coexist peacefully" (Sep. 19, 2000), "I understand small business growth. I was one" (Feb. 19, 2000), and the best-known "They misunderestimated me" (Nov. 6, 2000). ${ }^{15}$ However, instead of making fun of some mispronunciations and confusions, one might point to the hidden truth and Bush's adherence to a dialectical rather than a logical notion of truth. In greeting a friend and pointing out that "He's one of the great Pennsylvania political families," Bush was simply conveying the sublime message that politics - as in his own case-is still very much family based, and that the merit of one's political achievement is a result from the family's influence. ${ }^{16}$ Although not adhering to the strict notion of logical truth, Bush's reflection on the family embededdedness of a political career exposes the simple ideology of individualistic society. The same dialectical logic is in place, when Bush describes the danger of war: "I think war is a dangerous place" (May 7, 2003). This explains the repercussions of war on a geographical area. Again the narrow confines of logical truth are surpassed for a more inclusive dialectical truth; after all, war transforms a previously peaceful place in a dangerous one. A last example confirms the conveyance of an underlying truth, when he

\footnotetext{
15 For the Bushism quoted please refer to: $<$ http://politicalhumor.about.com/library/blbushisms.htm $>$ (on Oct 29, 2008).

${ }^{16}$ An insight that should be especially plausible in the social context of the Philippines. Bush's full quote runs as follows: "I'm so pleased to be able to say hello to Bill Scranton. He's one of the great Pennsylvania political families" (Sept. 15, 2003).
} 
discloses politics as rhetoric: "[T]hat's just the nature of democracy. Sometimes pure politics enters into the rhetoric" (Aug. 8, 2003). However, even with his sophistication Bush could not surpass the Hegelian spirit of former U.S. Vice President Dan Quayle, who commented on the problem of environmental damage: "It isn't pollution that's harming the environment. It's the impurities in our air and water that are doing it." 17 Along the line of the Hegelian dialectic, Quayle opposes the particular and the general, pointing out the non-identity of the different stages in the development of a concept, ascending from the concrete facts, to the generalized description.

The republican Vice-Presidential candidate Sarah Palin got a similar reputation as Bush following some problematic interviews in major television networks. One commentator even said that she makes Bush look like an intellectual. Well known are her claim of foreign policy experience by mere geographical proximity to Russia and her lack of knowledge of broader economic questions like the working of the bailout. ${ }^{18}$ However, like in the case of the outgoing president the public might "misunderestimate" (Bush) Palin's dialectical logic. Her answer to the question whether we need to go to war against Russia, if Georgia joins the NATO, took into account not only the binding legal obligation (NATO allies have to support one another if attacked), but also American exceptionalism. Her answer "Perhaps so" (Sept. 11, 2008), although not in line official NATO policies, takes in account the very real American exceptionalism. ${ }^{19}$ In a Hegelian framework one could say that Palin points out the difference between abstract right and "ethical life" [Sittlichkeit] being aware of the lack of abstract right as such to be implemented without concrete historical powers supporting it. ${ }^{20}$ Another example of a misunderstood insight of her is the remark about the "real America" which can be found in the small towns, where "hard working very patriotic" people live. ${ }^{21}$ Indeed, the real America lives there. Palin points out in this often criticized quote the normative standard of being American, which cannot simply be acquired by citizenship. The German philosopher Johann Gottlieb Fichte once said that one cannot be born as a German, one can only become German. In the same vein, Palin pointed out that being American—as it is understood throughout the prevalent American discourse-is something acquired a form

\footnotetext{
17 Although sometimes attributed to George W. Bush, a variety of sources in the world wide web confirm former US Vice President Dan Quayle as the authors. (e.g.

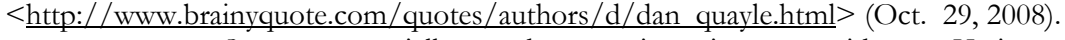

18 See especially her interview with Katie Couric, $<$ http://www.cbsnews.com/stories/2008/09/24/eveningnews/main4476173.shtml > (Oct. 30, 2008).

19 For this and the following Palin quotes see

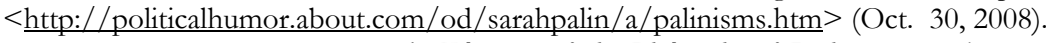

${ }_{20}$ G. W. F. Hegel, Elements of the Philosophy of Right, trans. by H.B. Nisbet (Cambridge: CUP, 1991).

21 "We believe that the best of America is in these small towns that we get to visit, and in these wonderful little pockets of what I call the real America, being here with all of you hard working very patriotic, um, very, um, pro-America areas of this great nation." (Oct. 16, 2008)
} 


\section{ADORNO, OBAMA, AND EMPIRE}

of life, which is not given by birth. Moreover, this form of life is oriented at some ideals, which are more incorporated in small town America.

Above I pointed out the dialectical logic Bush subscribed to. In various Palin quotes the same logic can be found. In a fundraising event, Palin spoke about "our neighboring country of Afghanistan" (Oct. 5, 2008) moving beyond the modern geographical understanding of neighbor, into the postmodern virtual age, where the world is not so much understood through the categories of space and time, but rather through a network of information. In such a world-view, proximity is defined not by space but rather by the different knots of a network, and given the U.S. involvement, Afghanistan indeed becomes a neighboring country of the United States.

Of course, this benevolent interpretation of Palin has its limits. Palin's attempt for example to overcome the mediatization of the election campaign is bound to fail. In the Vice-Presidential debate Palin seemingly overcomes the German idealism and the notion of only mediated knowledge of things themselves. Instead of speaking through the distorting media, she turns in a Husserlian way back $z u$ der Sache selbst [to the thing itself], disregarding the question of the moderator in the vice-presidential debate and talking straight to the people: "And I may not answer the questions that either the moderator or you want to hear, but I'm going to talk straight to the American people" (Oct. 2, 2008). Doing that on different occassions while at the same time speaking through media is nothing short of a performative contradiction; denying the media mediation while completely relying on it.

Related to this attempted unmediatedness is Palin's alleged authenticity. Mark Steyn in the National Review attributes to Sarah Palin an "authentic authenticity"22. And he even might be right, especially in the light of Adorno's Jargon of Authenticity (1973). Although directed against the "ontology" of Heidegger, Adorno's polemic against Heidegger's authenticity might well apply to Palin too. Adorno points out the construction of authenticity, which is not an unmediated attribute, to be found in simple and pre-reflexive way of life. Authenticity rather is already constructed. Palin's appeal stems partly from being authentic - a real person in the whole Washington political circus. This authenticity, however, rather than being the unmediated reality is a constructed brand known to be successful with the electorate. Palin's "authentic authenticity," thus, fails to be truthful in the same way as her attempt to speak directly to the American people bypassing the media is an impossible task in the area of media politics.

\footnotetext{
22 Mark Steyn, "With a Wink and a Smile," in National Review Online (October 4, 2008)<http://article.nationalreview.com/?q=ZmNjYTc3NzFiZGU1NjM2YmQ3NmMzNTM3 NiJlNGMzMjU>, October 31, 2008. See also Jon Meacham's article "Palin is on the ticket because she connects with everyday Americans," in Newsweek (October 13, 2008$), 37$.
} 


\section{Part II: Obama and Philosophy}

In the first part of this paper, I pointed out different aspects of the form of the U.S. election process, without entertaining thoughts about the content. In this second part, I will focus on three aspects of Obama's political philosophy, relating it to the notion of Empire (1), searching for foundational principles in his own work (2), and lastly interpret Obama as a postmodern symbolic political figure (3).

\section{The return of Empire?}

In their widely acclaimed book Empire (2000), Michael Hardt and Antonio Negri reflect on the logic and implications of globalization trying to make sense of the post-Cold War area with yet another meta-narrative framework. Writing during the Clinton era of the $90 \mathrm{~s}$, they call our time the age of Empire. It is characterized by a figurative end of history, where a marked-based economic outlook married to liberal democracy has prevailed. It is a time which is governed by low-key conflicts-Iraq 1991, Bosnia, Somalia-better to be understood as police interventions of a global Empire, rather than through the old concept of wars between nations. Empire then does not simply refer to the United States, but rather describes a transfer of sovereignty-military, economic, cultural and political-to the transnational level.23 Empire marks the transition to a truly global capitalism with an increasing flow of goods, services, labor across the globe unhindered by national regulation and boundaries. But unless the Roman Empire, to which the book alludes on different occasions, modern Empire does not have a capital where power is accumulated, but rather is a network of power-relations with different nods, but no single center. While in ancient Rome power could be acquired by overthrowing the Roman Emperor, modern Empire does not provide such a center. In other respects the Roman Empire is akin to modern (or post-modern) Empire: the street system of ancient Rome finds its parallel in the information highways of today, which not only provide unity for Empire, but are crucial for its functioning. More importantly, in its own understanding it is without limit in space and time, it covers the whole of the globe and does not conceive itself as limited in time. In this sense, Empire suspends history. The established perpetual "peace," however, like the famous pax romana, goes hand and hand with a ruling logic based on exploitation and expropriation. It is a peace based on repression. The counter player of this force of exploitation, Empire, is the desire and creativity of so-called multitude, which takes the logical place of the old Marxist concept of the proletariat or working class.

However, the terrorist attacks of 9/11, the succeeding government measures of control and especially the war in Iraq signified an important shift

${ }^{23}$ Antonio Negri, Negri on Negri, trans. by M.B. DeBevoise (New York: Routledge, 2004), 60 . 


\section{ADORNO, OBAMA, AND EMPIRE}

in the global political order. The measures of control reinforced the power of national government, while the unilateral war on Iraq was a step back from Empire into old-fashioned imperialism. In an article written months before the Iraq war, Michael Hardt interprets the impending U.S. invasion as an act against the very interests of Empire. ${ }^{24}$ Having said all this I return to the initial question, namely whether we can expect a return to Empire.

A cautiously positive answer can be given because of the following four points: the first thing that is noteworthy of Obama's reading of world history is his at times critical attitude towards US foreign policy of the past, speaking for example of "thousands of U.S. troops crushing a Philippine independence movement" 25 pointing out that the United States was barely distinguishable at that time from European colonial powers. Although being aware of the doubtful American foreign policy during the Cold War by backing dictatorships just for the sake of their being against communism, Obama understands this history as a journey towards the promotion of democracy worldwide, and he tirelessly emphasizes the need to unite the international community to foster global democracy. This is certainly a sign of return from imperialism to Empire. Although, as part of the entire American rhetoric, even though he would not put it as bluntly as McCain who sees the U.S. as the major force for good in today's world, Obama would still maintain the exceptionalism that characterizes the foreign policy of the United States for so long.

The second point is Obama's thought on the changes required in warfare or the conditions on which a war is won is quite similar to Hardt and Negri's account of was in Multitude, albeit from a different angle. Hardt and Negri take a look, on the one hand, on the transformation of warfare from the point of view of the military and, on the other hand, from the point of view of resistance to hegemonic power. The military has transformed from a strictly hierarchical and centralized structure, where communication is solely running vertically, and where nothing mattered but firepower a hundred years ago, to a more complex organization, where information needs to be widely shared, where not only military skills matter, but social, language, cultural skills as well. Obama is aware of this transformation of the military and the need to push it even further. The military need to be trained, as Obama writes, "in the language, reconstruction, intelligence gathering, and peacekeeping . . . to succeed in increasingly complex and difficult missions."26 Obama here echoes Hardt and Negri's account of the transformation of warfare, which requires dominance not only in terms of firepower, but also on social, cultural and ideological level. To win a war, as Obama, Hardt and Negri would agree, one has to prove the superiority of one's set of values in the eyes of international public opinion.

${ }^{24}$ Michael Hardt, "Folly of our masters of the universe," The Guardian, December 18, 2002, < http://www.guardian.co.uk/comment/story/0,3604,861942,00.html>.

${ }^{25}$ Barack Obama, The Audacity of Hope. Thoughts on Reclaiming the American Dream (New York: Random House, 2006), 333.

${ }^{26}$ Ibid., 363. 
A third point is Obama's emphasis on the creativity and ingenuity of the multitude, which built up the enormous wealth of the Western world. Throughout his public life and especially throughout his campaign, Obama was emphasizing the grassroots, the bottom-up approach etc. Already in his early memoir "Dreams from my father" (first published in 1995), Obama emphasizes this approach, explaining his choice to become a community organizer in Chicago after his undergraduate degree in political science. The terms he used in order to explain his reason for becoming a community organizer resonates with his campaign for president: "Change will come from a mobilized grass roots. That's what I'll do, I'll organize black folks. At the grass roots. For change." 27 Moreover, this organization of the community happens by rally people behind a common topic against the enemy, which Obama's boss at that time identified as: "The investment bankers. The politicians. The fat cat lobbyists." 28 The pattern to be seen in Obama's community organizing effort is thus a similar one to Hardt and Negri's invocation of the power and creativity of the multitude, which is captured and alienated by Empire. Hardt and Negri's advocacy of autonomous, selfsufficient, self-organizing communities that resist capitalist logic is similar to Obama's community organizing effort. Although Obama would not subscribe to the academic radicalism of Hardt and Negri, rather he would emphasize the importance of bringing about equilibrium of power by giving a suppressed community a voice.

In a last respect there can be seen a parallel between Obama's beliefs and the account put forward in Empire and Multitude. It is the appreciation for an idealistic interpretation of the American Constitution. Hardt and Negri use an idealized, globalized version of it in order to advocate an empowerment of the multitude, claiming that today's revolutionary is somehow between the Russian revolutionary Lenin and American constitutionalist Madison, bringing together the revolutionary change and the republican empowerment. ${ }^{29}$ Obama, who taught constitutional law at the University of Chicago, dedicates a whole chapter in the "Audacity of Hope" to the U.S. Constitution understanding democracy "not as a house to be built, but as a conversation to be had." 30 In a similar vein, the politician and the philosophers refer to Jefferson's advice to "engage in a revolution every two or three generations." 31

In short, as president Obama might reverse the imperialist turn that U.S. foreign policy took in the last eight years and return to a more inclusive Empire-like foreign policy, which understands global politics as a field where police interactions are required, but where aggressive promotion of interest primarily by military means fades. Hardt and Negri have no doubt that Empire

\footnotetext{
27 Barack Obama, Dreams from my Father. A Story of Race and Inheritance (New York: Random House, 2004), 133.

28 Ibid., 150.

${ }^{29}$ Michael Hardt and Antonio Negri, Multitude. War and Democracy in the Age of Empire (New York: Penguin Press, 2004), 348f.

30 Obama, The Audacity of Hope, 110.

${ }^{31}$ Ibid., 111. See Hardt and Negri, Multitude, 248.
} 


\section{ADORNO, OBAMA, AND EMPIRE}

is still oppressive, but they would argue that it allows the multitude a better organization and development of its creativity.

\section{Obama's political philosophy}

The first question to ask is whether Obama has a political philosophy. The answer might well be yes and no. On the one hand his views cannot simply be attributed to a clear philosophy; he borrows too widely from different traditions. More intriguing, when asked about his favorite philosopher, he refers to Reinhold Niebuhr more known as a theologian than a philosopher. There is no clear-cut view of his philosophical background. This absence of philosophical foundation led the historian Fred Siegel say that Obama has "a rhetoric rather than a philosophy" 32 and that ambition is his only philosophy.

However, dwelling on his own writings one might well try a reconstruction of the fundamentals of his political outlook. In his second book written as a senator probably in preparation for higher office, Obama explains why he embarked on studying political philosophy. He pictures himself as a combination of his absent father's ambition and his mother's values. Writing about his mother's fundamental convictions instilled in him, Obama writes that he studied "political philosophy, looking for both a language and systems of action that could help build community and make justice real." 33 With his undergraduate degree from Columbia University in political science, Obama then worked as a community organizer in order to practically apply these very ideals.

These two notions stand at the core of Obama's political vision: community and justice. Community can be seen as the major focus of politics in order to bring about change, while justice is the normative ideal. Obama's focus on justice resonates with classical Third Way politics as practiced in social democratic European states in the last decade. Outlined by Anthony Giddens, Justice in the Third Way has not to be understood in terms of an equal distribution of wealth, as classical socialism would have it, rather it is understood in terms of inclusion and exclusion. ${ }^{34}$ Giddens' focus is to reintegrate people at the margins, making sure that opportunities are available for everyone. Obama stresses this notion of opportunity, and when he speaks of justice, then it is a justice of opportunity (what he refers to as the American Dream). He refers to Lincoln for whom "the essence of America was opportunity, the ability to 'free labor' to advance in life." 35 The tool to establish this equality of opportunity is a sort of New Deal 2.0, which Obama considered as a policy option already before the advent of the current financial

32 Quoted in Michael Powell, "Tracing the Disparate Threads In Obama's Political Philosophy," in New York Times (August 25, 2008).

33 Obama, The Audacity of Hope, 244.

${ }^{34}$ Anthony Giddens, The Third Way. The Renewal of Social Democracy (Cambridge: Polity Press, 1998), 102f.

35 Obama, The Audacity of Hope, 179. 
crisis. ${ }^{36}$ Part of such a deal is what Giddens calls positive welfare focusing on counseling rather then on material support if possible. ${ }^{37}$

However, Obama's strong focus on community, close to communitarianism is at odds with the classical Third Way perspective and is somewhat disturbing for philosophical liberals. Communitarianism stresses the importance of the communal-community, religion, state - and its hold over the individual. Obama makes this influence explicit when he writes in his early book: "I can see that my choices were never truly mine alone-and that that is how it should be, that to assert otherwise is to chase after a sorry sort of freedom." 38

\section{Obama as a Postmodern Figure}

A very telling moment in the presidential race was the answer that both candidates gave to the question of evil. While McCain put emphasis on defeating evil following an unreflected friend-enemy logic, Obama on the other hand pointed out that erasing evil from the world is God's task and we might only be His servants in the process. He then added: "Now, the one thing that I think is very important is for us to have some humility in how we approach the issue of confronting evil, because a lot of evil's been perpetrated based on the claim that we were trying to confront evil." 39 In his books, Obama reflects on the problem of evil further pointing to the circumstances that produce evil, how lives can be twisted by poverty and powerlessness in places like the slums of Jakarta or suppressed regions in the inner-city of Chicago. Obama is moving beyond the bipolar world-view, the dichotomy between good and evil, and realizes that evil is produced by wretched social conditions.

A second aspect in which Obama differs radically is on his postmodern identity, whereas Palin is the exact opposite. "Palin is not regarded as an introspective or intellectual type . . .. In that sense, she's the antiObama."40 Obama spent large part of his life in Hawaii and Indonesia away from American mainland and living in different urban centers engaged in a lasting search for his identity, "Sarah Heath Palin seems just fine being a woman of Wasilla." 41 Post-modern constructed identity meets the modern one. Obama in this regard transcends modern identity politics.

Finally, the question whether Obama is a "transformational figure" (Colin Powell) who will bring people together or whether he is far to the left was discussed throughout the final month of the campaign and has to be seen.

36 "The last time we faced an economic transformation as disruptive as the one we face today, FDR led the nation to a new social compact-a bargain between government, business, and workers that resulted in widespread prosperity and economic security for more than fifty years." Ibid., 209.

${ }^{37}$ Giddens, The Third Way, 115.

38 Obama, Dreams from my Father, 134.

39 This discussion on evil was part of the joint appearance of both candidates at the Saddleback Church in August 2008, answering the identical questions in back-to-back sessions.

${ }^{40}$ Jeffrey Bartholet, "An Apostle Of Alaska," in Newsweek (September 15, 2008$), 28$.

${ }^{41}$ Ibid. 


\section{ADORNO, OBAMA, AND EMPIRE}

Michael Gerson, in the Washington Post, would understand Obama's creed as "the Platonic form" (Oct. 22, 2008) of liberalism. What is however undisputed is the symbolism of his election, perhaps best captured by the tears of Jesse Jackson, himself an unsuccessful candidate running for president in the 80s: On the one hand, the election of Obama offers redemption for a past characterized by racism and oppression, on the other hand Jesse Jackson's tears symbolizes the nation's remaining scares. Explaining his feelings on election night, Jackson referred to the joy he felt about this historical moment, but also about the suffering endured throughtout the sorrowful African American past; a past-as Faulkner puts it and Obama often quotes_- "that is never dead. It's not even past." The historical dimension of the election, evoked by many in the news media, has to be coined also on the past of repression and slavery of the U.S., which came to presence. Obama's election was not only joined by relief about the overcoming of racial boundaries. It also brought to mind the long, painful process and the many sacrifices required to reach this point.

Department of Philosophy, Ateneo de Manila University, Philippines

\section{References}

Adorno, Theodor W., Minima Moralia. Reflections from Damaged Life, trans. by E.F.N. Jephcott (London: NLB, 1974)

Problems of Moral Pbilosophy, trans. by Rodney Livingstone (California: Stanford University Press, 2001). , "Wissenschaftliche Erfahrungen in Amerika," in Gesammelte Schriften (Band 10.2) (Suhrkamp: Frankfurt am Main, 1997), 702-738.

, The Jargon of Authenticity, trans. by Knut Tarnowski and Frederic Will (London: Routledge, 1973).

Bartholet, Jeffrey, "An Apostle Of Alaska," in Newsweek (September 15, 2008).

Dietl, Helmut and Franck, Egon, "Das Frühstück der Nationalspieler interessiert mehr als der Staffelrekord," in Neue Zürcher Zeitung (June 17, 2008), 55.

Gerson, Michael, "The Irony of Obama," in Washington Post (October 22, 2008).

Giddens, Anthony, The Third Way. The Renewal of Social Democracy (Cambridge: Polity Press, 1998).

Hardt, Michael and Negri, Antonio, Empire (Harvard: Harvard University Press, 2000). Multitude. War and Democracy in the Age of Empire (New York: Penguin Press, 2004).

Hardt, Michael, "Folly of our masters of the universe," in The Guardian (December 18, 2002) < http://www.guardian.co.uk/comment/story/ $\underline{0,3604,861942,00 \cdot h t m l}>$.

Hegel, Georg Wilhelm Friedrich, Elements of the Philosophy of Right, trans. by H.B. Nisbet (Cambridge: CUP, 1991). 


\section{KAELIN 45}

Horkheimer, Max and Adorno, Theodor W, Dialectic of Enlightenment, trans. by John Cumming (New York: Continuum, 1972).

Meacham, Jon, "The Palin Problem," in Newsweek (October 13, 2008).

Negri, Antonio, Negri on Negri, trans. by M.B. DeBevoise (New York: Routledge, 2004).

Obama, Barack, The Audacity of Hope. Thoughts on Reclaiming the American Dream (New York: Random House, 2006).

Dreams from my Father. A Story of Race and Inheritance (New York: Random House, 2004).

Powell, Michael, "Tracing the Disparate Threads In Obama's Political Philosophy," in New York Times (August 25, 2008).

Steyn, Mark, "With a Wink and a Smile," in National Review Online (October 4, 2008) <http://article.nationalreview.com/

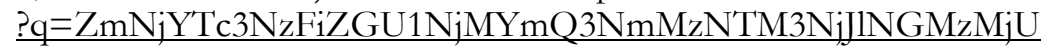
$>$, October 31, 2008. 